\title{
The Integration of Innovative Entrepreneurship Education and Interior Design Specialty Education in Higher Vocational Architecture
}

\author{
Wenjun $\mathrm{Xu}^{1}$ \\ ${ }^{1}$ Jiangxi Vocational Technical College of Industry \& Trade, Nanchang, Jiangxi, 330038, China \\ Research on the talent training model of "three advances, two creations" based on the background of double innovation
}

\begin{abstract}
As a subject with strong application, interior design is intended to guide students to use design concepts and technical means scientifically according to the nature and standards of architecture, so as to create the indoor environment that people need. With the innovation of Internet technology and the rapid development of innovation and entrepreneurship, the integration of innovation and entrepreneurship education and interior design education in higher vocational buildings has become an inevitable trend of talent training. However, at present, there are still some problems in the innovation and entrepreneurship education of interior design major in China, such as the imperfect curriculum system, the insufficient degree of integration of curriculum and specialty, the weak spirit of innovation and entrepreneurship of higher vocational students, the insufficient ability of innovation practice and the lack of practice. In view of this, on the basis of experience at home and abroad, this paper tries to put forward the integration way of innovative entrepreneurship education and interior design professional education from the aspects of the reform of talent training mode, the innovation of curriculum system, the construction of practical platform, and the construction of teaching staff, in order to achieve better educational effect.
\end{abstract}

\section{Introduction}

Education is a wide range of work, education is not only to teach students knowledge and how to be a man, but also to cultivate students' certain ability. The new curriculum standard puts forward that the goal of cultivating students' innovative thinking and ability should be carried out in order to achieve this goal. At present, the education of many higher vocational colleges is closely related to the students' future occupation. It is often necessary to cultivate students' innovative spirit and innovative thinking through innovative entrepreneurship education, and to train students' innovative entrepreneurial ability. The integration of innovative entrepreneurship education and interior design education in higher vocational buildings is also the development trend of the times, the demand for cultivating talents in the new era, and the better development of students. Starting with the reform of interior design education in higher vocational colleges, this paper introduces the concrete reform measures of the integration of innovative entrepreneurship education and interior design specialty in higher vocational colleges.

\section{Domestic and Foreign Case Study}

\subsection{Study on Teaching Method in the Teaching of Innovative Entrepreneurship Education}

Foreign innovative entrepreneurship education started a lot earlier than China, so far has been very mature, and the teaching method is flexible and diverse, the effect is also very high. This is worthy of our recognition, than Chinese excellent way of education is worth learning[1]. However, due to the cultural and educational background differences between China and foreign countries, not all successful experiences can be applied to our education, but there are still many successful cases that have a great guiding role in the current innovative entrepreneurship education in China.

First of all, the United States, in innovative entrepreneurship education, focus on market guidance, imitation operation, to create an innovative entrepreneurial atmosphere. They will ask teachers to go to the company to participate in real entrepreneurial activities, so that teachers as a pioneer, have a certain leading role. Moreover, they also require students to participate in the whole operation of the enterprise at the beginning. Secondly, Britain pays more attention to cultivating students' entrepreneurial quality. There are a variety of 
teaching methods, such as team project homework, case teaching, guest interaction, entrepreneurship lectures and summer schools. The curriculum system is divided into "about entrepreneurship" and "for entrepreneurship" courses. Secondly, Germany, half of the universities in Germany are based on innovation and entrepreneurship, the development orientation is based on applied innovation, and more and more colleges and universities in the later period are based on this development. The last country to analyze is Japan, which has always attached great importance to education. Japanese mass entrepreneurship and innovation education is characterized by technical education as the focus, using the credit system, the higher the credit, the better. And Japan takes the occupation demand as the direction, trains the occupation idea, sets up the lifelong learning pioneering idea, trains the basic technology principle to train the innovation occupation technology innovation entrepreneurship education[2].

\subsection{Development of Innovative Entrepreneurship Education in Higher Vocational Colleges}

The innovation and entrepreneurship education in foreign countries is in sharp contrast with the development of innovation and entrepreneurship education in higher vocational colleges in China. The teaching of many higher vocational colleges in China is too simple, but it is very systematic to teach the theoretical knowledge to the students, and there is a phenomenon of full irrigation. Many times, the courses set up in colleges and universities in China are out of touch with the major, which is not helpful to the major. The second is not to pay attention to the cultivation of entrepreneurial spirit. The education of China pays more attention to the cultivation of examination-oriented education, pays attention to the score, and is not enough to cultivate the students' entrepreneurial spirit and entrepreneurial ability[3]. Third, the mechanism is not perfect, these are the main problems of innovative entrepreneurship education in higher vocational colleges in China. The innovation and entrepreneurship education in higher vocational colleges in China started relatively late, but in recent years, the china has gradually paid attention to it. In recent years, innovative entrepreneurship education and traditional professional education in higher vocational colleges in China are merging with each other, adhering to the principles of pertinence, divergence and applicability. Successful cases are: Yantai Vocational and Technical College and high-tech enterprises to develop products, improve the innovative ability of teachers and students.

\section{Some Problems of Innovative Entrepreneurship Education for Interior Design Specialty}

At present, there are still some problems in innovative entrepreneurship education for interior design of architecture, which also exist in innovative entrepreneurship education in higher vocational colleges.

\subsection{The curriculum system of innovative entrepreneurship education is not closely integrated}

Now with the continuous development of society and the rapid development of our economy, the per capita life of our people has been greatly improved, and the housing and diet have higher requirements. Therefore, the training of interior design professionals is also more urgent. At present, in order to train architectural interior design professionals in higher vocational colleges, we have proposed to increase the general courses of innovative entrepreneurship education and professional innovation courses, but because of the lack of professional teachers in the general courses of innovative entrepreneurship education, the teaching method is not professional enough. There is also a problem, Chinese professional innovation and entrepreneurship curriculum is lack of practice, cooperation with enterprises is not close enough, and the teacher's teaching method is single, it is difficult to cultivate students' innovative entrepreneurial quality. Moreover, if professional teachers do not attach importance to innovative entrepreneurship education teaching methods, and innovative entrepreneurship education and professional education are not integrated together, it is difficult to cultivate students' innovative entrepreneurial ability, and the effect of innovative entrepreneurship education in the whole higher vocational college will be not good[4].

\subsection{The innovation and entrepreneurship ability of higher vocational colleges is weak}

Compared with the students in higher vocational colleges, the students in higher vocational colleges have weak ability of innovation and entrepreneurship, low consciousness of learning and low academic level, but the students in higher vocational colleges have strong drive. Often have great interest in entrepreneurship. In recent years, more and more students graduated from interior design major, and they started their own business more and more, but starting a business is not an easy thing, need a lot of things. Students in higher vocational colleges always have blind self-confidence, perhaps not enough professional understanding, not enough understanding of the market[5], often lack of innovation, not enough professional learning in school, resulting in too low technical level, not strong ability to act, and the ability to resist pressure is not good, or eventually led to entrepreneurial failure. Therefore, it is very important to strengthen the students' innovative thinking and entrepreneurial temperament in higher vocational colleges, and to strengthen the ability of students to resist pressure, which is very important for some students who are very interested in entrepreneurship.

\subsection{Lack of practical safeguards}

Higher vocational colleges pay attention to the cultivation of technical talents, often pay more attention to the cultivation of vocational skills, and emphasize the deep 
integration of schools and enterprises, so it is helpful for higher vocational students to start a business. To successfully start a business, enterprise innovation is essential, so to have innovation in the profession, we must have a deep understanding of the basic knowledge of the profession, and have a good understanding of the prospects of the profession. Now China is still examination-oriented education, so students occupy most of the time in learning theoretical knowledge, but practice lacks the opportunity. At present, the credit recognition and evaluation rating system of innovative entrepreneurial activities in many higher vocational colleges is not perfect, and there is no good coordination between departments. Students should participate in innovative entrepreneurial activities and competitions more, and put forward some problems in schools, such as no time to practice, too much class time, and lack of practical protection[6].

\section{Innovation and Entrepreneurship Education and Reform Measures for the Integration of Interior Design Education}

\subsection{Try to reform the pattern of cultivating talents in different sections}

The main idea of innovative entrepreneurship education is not to judge the success of education by whether or not we can innovate and start a business, nor to let students start a business, but to cultivate students' consciousness of innovation and entrepreneurship. Teachers can no longer teach knowledge to students in such a general way, but should teach students according to the characteristics of different age groups, have methods to teach students, but also let students choose appropriate methods to learn according to their own characteristics.

In the interior design major of higher vocational architecture, freshmen mainly study some basic courses without taking the measures of dividing classes, such as three major components of interior design course, sketch, color and drawing, as well as basic cultural courses such as English, computer and so on. At the same time, we should listen to more professional lectures, broaden our knowledge horizons, understand other people's successful cases, learn successful experiences, plan our college life, and adapt to the changes from high school life to college life. You can learn to learn independently in your study[7].

After the freshman lays a good foundation, in the sophomore year, the student should go to the practice aspect to exercise, may sign up to participate in the innovation pioneering competition, exercises own pioneering ability, also has the pressure resistance ability. Schools can also choose some students with innovative thinking and suitable for entrepreneurship to enter the design and entrepreneurship center through some innovative entrepreneurial activities or competitions, and train students according to the innovative entrepreneurship training program. The design and entrepreneurship center is mainly to train students with entrepreneurial ability, to receive design orders from schools, and to create value for enterprises. In the design of entrepreneurship center, we can not only exercise our own innovative entrepreneurial ability, but also take different credits according to the difficulty of different projects, exercise ourselves in study, and bring benefits to enterprises.

\subsection{Curriculum reform}

If students' theoretical knowledge and practice are well combined, the curriculum system needs to be reformed. Building interior design professional innovation and entrepreneurship curriculum reform as follows:

First, the curriculum should be aimed at all students and set up a compulsory course for general knowledge of innovation and entrepreneurship[8]. In order to enable students to master the basic knowledge of professional courses and let students understand the employment prospects and employment trends of their major, Give students better protection. Through the guidance of general knowledge curriculum, we can cultivate students' innovative entrepreneurial thinking, give students entrepreneurial methods, and organize a certain number of teachers of general knowledge curriculum. Second, for all students, set up professional innovation and entrepreneurship elective courses to enrich students' theoretical knowledge. Because higher vocational colleges have only three years system, the elective courses in previous years will be offered in junior high school. Now the elective courses will be offered in freshmen and sophomores, and attention will be paid to the cultivation of innovative entrepreneurial thinking ability from the beginning of admission. Third, for the students of the design and entrepreneurship center, the course of "work operation and management of interior design room" is set up, and professional lectures and case analysis courses are set up to enrich the students' cultural literacy.

Table1. Innovative Entrepreneurship Curriculum

\begin{tabular}{|l|l|l|l|}
\hline the type of course & course title & Opening term & $\begin{array}{l}\text { class } \\
\text { period }\end{array}$ \\
\hline $\begin{array}{l}\text { Liberal Studies } \\
\text { in Innovative } \\
\text { Entrepreneurship }\end{array}$ & $\begin{array}{l}\text { College } \\
\text { Students' } \\
\text { Innovation and } \\
\text { Entrepreneurship } \\
\text { Foundation }\end{array}$ & $\begin{array}{l}1-4 \\
\text { semesters }\end{array}$ & $\begin{array}{l}8 \text { hours } \\
\text { per } \\
\text { semester }\end{array}$ \\
\hline $\begin{array}{l}\text { Professional } \\
\text { Courses in } \\
\text { Innovative } \\
\text { Entrepreneurship }\end{array}$ & $\begin{array}{l}\text { VR Design } \\
\text { Innovation }\end{array}$ & Semester 3 & 16 hours \\
\hline
\end{tabular}

\subsection{Actively create practice platforms}

Higher vocational colleges should create a practical platform to provide students with entrepreneurial guidance, take the current environment of enterprises as the starting point, integrate the concept of entrepreneurship, and carry out field teaching. In order to make students participate in practice better, higher vocational colleges should work together with the school and cooperative enterprises to let students participate in the company's interior design projects, adopt case teaching method and project teaching method, and encourage students to participate actively. Integrate practical entrepreneurial activities into field teaching. Higher vocational colleges should adhere to the 
principle of "combining theory with practice" to give students more real practical experience. Higher vocational colleges should also often hold innovation and entrepreneurship competitions, so that students can actively participate in innovation competitions and innovative design competitions, exercise students' innovative thinking, improve learning efficiency, and create a good atmosphere for innovation and entrepreneurship. Cultivate the spirit of active learning[9].

\subsection{Strengthening the Construction of Teachers in Innovative Entrepreneurship Education}

When teaching general courses and interior design courses, teachers should strengthen students' understanding of basic knowledge and pay attention to cultivating students' innovative thinking and comprehensive quality of entrepreneurship. Teachers should adhere to the educational concept of lifelong learning, enrich their knowledge reserves, and often participate in enterprise practice exercise to improve their professional ability. Teachers should stand at the forefront of the industry in order to know the latest developments of the major, to guide students and guide students to professional innovation. Now the Internet age is so developed and many materials can be queried online. If teachers do not understand the latest knowledge faster and earlier, how do them educate and train students? Therefore, it is necessary to ensure teachers' strength, promote teachers' continuous learning, and include performance appraisal, so that teachers can become the core force of innovative entrepreneurship education.

\subsection{Cultivating Students' Comprehensive Quality of Entrepreneurship}

The emphasis of innovative entrepreneurship education is to cultivate students' comprehensive quality. In order for students to successfully start a business, first of all, we should cultivate students' awareness of innovation and entrepreneurship, let students feel that innovation and entrepreneurship is a meaningful thing in their hearts, improve students' learning motivation, and let students study actively. Consciously develop good habits. Teachers should also cultivate students' team spirit and develop students' organizational, communication, leadership, analytical and management skills in the team. In innovation and entrepreneurship, all members of a team need to communicate with each other and analyze together[10]. The core characters of a team need certain organizational and management skills, which can better carry out innovation and entrepreneurship. Innovation and entrepreneurship is not an easy thing, often experience some failures and setbacks, perhaps not a failure twice, many failures are possible. This requires entrepreneurs to have a strong psychological tolerance, so also to develop students' ability to resist pressure and failure of emotional management.

Through the cultivation of comprehensive quality of innovation and entrepreneurship, we can increase the cultivation of students' learning ability and professional accomplishment, and make professional education and innovative entrepreneurship education merge together and complement each other. At the same time, we should combine the basic knowledge of the major with the concrete practical activities, integrate the knowledge, ability and quality, and improve the students' ability of innovation and entrepreneurship. Education in the past is a form of "spoon-feeding ", which only inculcates theoretical knowledge and does not teach according to students' different conditions. Now the education has changed, students can choose suitable learning methods according to their own ideas and characteristics, learn more knowledge and master more practical skills in innovative entrepreneurship education[11].

\subsection{Reform mechanisms}

In order to better realize the education of innovation and entrepreneurship, coordinate various factors and promote the better development of innovation and entrepreneurship. Higher vocational colleges should establish administrative system management, establish a department, set up administrative personnel, professional teachers and counselors to jointly help the development of innovative entrepreneurship education, and can set up funds or bonuses to encourage teachers and students to actively participate in innovative entrepreneurial activities. Only by joining in innovative entrepreneurial activities can we really get exercise. There is a good saying: the paper will eventually feel shallow, never know the matter to practice.

\section{Conclusion}

China has changed from a big agricultural country in the past to a big economic country in the present, from "made in China" to "Chinese wisdom ", so the demand for talents in China is increasing, especially professional talents and original talents. In the present society, there is no shortage of highly educated people, lack of innovative talents. Now with the continuous development of society, the continuous improvement of people's living standards, the demand for housing is also increasing, so for the architectural interior design major is a new opportunity, in the future has unlimited prospects. Now the interior design specialty trains the technical talented person, must adapt to the development of the times actively, unifies with the Internet. Higher vocational colleges require to improve students' innovative entrepreneurial ability and develop students' innovative thinking in order to become a qualified talent in the new era. Because students in higher vocational colleges have a strong desire to start a business, they should exercise the practical ability of students in higher vocational colleges, use innovative entrepreneurship education to build a platform for students, and provide students with more practical opportunities. The integration of innovative entrepreneurship education and professional development education is the inevitable trend of the development of education industry and the new standard of Chinese new curriculum standard. The combination of the two can help students to learn professional knowledge better, promote the teaching of 
innovative entrepreneurship education, improve the quality of innovative entrepreneurship of college students, and thus promote the development of innovative entrepreneurship education in the future.

\section{References}

1. Xu,S.P.Shi,X.H.(2016)A Review of the Research on Innovation and Entrepreneurship Education in Foreign Colleges and Universities 1 Also on the Path Exploration of Innovation and Entrepreneurship Education in Chinese Colleges and Universities[J]. Journal of Qujing Normal University.

2. Mei,W.H.(2010) Entrepreneurship Education in American Universities[M]. Hangzhou: Zhejiang Education Press.

3. Qiao,M.Z.Chen,Z.W.(2009 ) Characteristics and Enlightenment of Entrepreneurship Education in British Universities[J].Foreign education research.

4. Chen,X.H.Lian,D.(2018)The Influence and Enlightenment of German Innovation and Entrepreneurship Education on Higher Vocational Education in China[J].Modernization of education.

5. Yu,M.(2016)Analysis and Reference on Innovation and Entrepreneurship Education in Japanese Universities[J]. Anhui Literature (Second Half Month).

6. Bai,L.J.(2016)On the New Normal University Innovation and Entrepreneurship Education[J]. Continuing education research.

7. Chen,Y.Zhang,L.P.Zhen,J.X.(2020)Integration of Innovative Entrepreneurship Education and Interior Design Education in Higher Vocational Architecture[J].Fujian Forestry Vocational and Technical College.

8. Wang,J.Jiang,C.H.(2016)Cultivation of College Students' Self-learning Ability and Comprehensive Quality in the Context of Innovation and Entrepreneurship[J].Exploration of Higher Education.

9. Meng,J.(2007)Training of Innovative Talents in Demand of High-skilled Personnel[J].Oil education.

10. Sun,X.D.Zhao,J.Wang,Y.Q.(20180Study on the Path of Cultivating College Students' Entrepreneurial Ability in the Context of Mass entrepreneurship and innovation[J].Science and Technology Wind.

11. Ma,H.M.Hao,M.Z.(2018)Cultivation and Promotion of College Students'Innovation and Entrepreneurship Ability $[\mathrm{J}]$.Education and Teaching Forum. 